\title{
A COMMEDIA DELL'ARTE E SUA REOPERACIONALIZAÇÃO
}

\author{
José Eduardo VENDRAMINI ${ }^{1}$
}

- RESUMO: Análise da commedia dell arte a partir de uma perspectiva histórico-crítica, enfatizando-se as várias maneiras de sua apropriação no século XX. Partindo de elementos da commedia dell'arte, serão ressaltados os temas da migração do teatro de praça para o teatro fechado e a ampliação do modelo da commedia dell'arte para outras formas artísticas do século $\mathrm{XX}$, como o cinema mudo, o circo e o carnaval.

- PALAVRAS-CHAVE: Commedia dell'arte; teatro de praça; teatro fechado.

A commedia dell'arte, tradição de teatro popular que vigorou na Europa durante os séculos XVI e XVII, não somente influenciou inúmeros dramaturgos e companhias teatrais de renome (como a Comédie Française, herdeira de Molière), nos mais diferentes países, como também deixou seu lastro naquelas outras companhias teatrais extremamente populares que, apesar do quase anonimato quanto ao registro histórico nos livros acadêmicos, mantiveram viva, até os nossos dias, a chama da arte ingênua dos saltimbancos, que pode ser detectada no cinema mudo e suas decorrências (Chaplin, Buster Keaton, Laurel \& Hardy, Os Três Patetas, comédias da Atlântida, Cantinflas), no circo, no cabaré (com Karl Valentin, que influenciou Bertolt Brecht, em sua fase inicial) e na revista musical.

1 Professor da Escola de Comunicação e Artes - USP - 05508-900 - São Paulo - SP. 
Conseqüência natural de uma linha ininterrupta de teatro popular, que começa com os Flíacos, ainda na Grécia Antiga, passando pelo teatro folclórico e pela Atelana, formas já oriundas da Itália, para não falar das fontes eruditas devidas a Terêncio e Plauto. Depois do seu apogeu, a commedia dell'arte vem pontuando a história do teatro de interferências de graus variados de intensidade, porém sempre inegavelmente significativas, marcando desde a carreira de clássicos como Goldoni (e seu opositor, Gozzi), Molière e Marivaux, como dos modernos que, já no século $\mathrm{XX}$, tanto do ponto de vista da dramaturgia quanto da direção teatral, retomam fórmulas e temas oriundos daquela forma do fazer teatral.

É importante notar que, no início do século XX, a retomada do modelo e - conseqüentemente - também dos temas da commedia dell' arte tem uma relação direta com a recusa do naturalismo por aqueles que se opunham à principal tendência do Teatro de Arte de Moscou, então trabalhando sob a égide carismática de Stanislavski.

Nesse sentido, pode-se pensar numa homologia: do mesmo modo que, nos séculos XVI e XVII, a commedia dell'arte se opunha frontalmente ao teatro literário que se fazia em palácios (leitura de peças em latim e representação de comédias totalmente escritas na linha da chamada Commedia Sostenuta), no século XX, a retomada da commedia dell'arte como modelo teatral também tem por objetivo a oposição a uma forma extremamente cristalizada de teatro, decorrente da exacerbação dos princípios do realismo pelo naturalismo que, em sua busca da "fatia da vida" no palco, tinha levado a arte em geral e a do teatro em particular ao beco sem saída da pulverização do signo artístico, suplantado pelo "Real" propriamente dito, procurado insistentemente em detrimento de sua representação artística, negando assim o que é, grosso modo, a diferença básica sobre a qual repousa a distinção fundamental entre vida e arte.

Forma de teatro pertencente ao passado, com a valorização da improvisação no século XX, decorrente tanto da ação dos grupos de vanguarda (happening, criação coletiva, performance), insatisfeitos com a dramaturgia que lhes era oferecida, quanto das recentes investigações nos campos do psicodrama, da arte-educação e da formação do ator, a commedia dell'arte tem revelado surpreendente modernidade para quem, em princípio, já foi considerada forma estratificada, museológica.

Mais uma vez, a própria arte se encarrega de desautorizar abordagens errôneas que lhe são impingindas: corrigindo a perspectiva historicista, diacrônica, que imobiliza no passado o fenômeno da commedia dell'arte, uma das vertente do teatro de vanguarda do século XX, ao recu- 
perar - entre outros elementos - o caráter de improvisação que caracterizava o teatro popular italiano, faz confluírem harmonicamente procedimentos teatrais antigos e modernos, numa atitude arejada e típica de uma postura que identifica não apenas a evolução seqüencial dos fatos, mas recuperações sincrônicas de estruturas fundamentais de momentos básicos da história do teatro, como é o caso da commedia dell'arte.

$\mathrm{O}$ tema proposto foi estudado, principalmente, por quatro grandes pesquisados: P. L. Duchartre (1955), C. Mic (1927), M. Apollonio e V. Pandolfi. Une-os a preocupação historicista que atravessa, com minúcias, a abordagem que cada um faz da commedia dell'arte, seus antecedentes e suas decorrências. Vale notar que as contribuições de P. L. Duchartre e C. Mic são complementares, devendo ser lidas em seqüência, uma vez que $\mathrm{C}$. Mic questiona e corrige, às vezes de forma veemente, muitos aspectos deixados obscuros ou lançados erroneamente por P. L. Duchartre, discordando dele em pontos fundamentais, o que faz da leitura conjunta de suas obras uma abertura tanto à polêmica quanto à busca da exatidão da informação procurada, no caso, a-histórica.

Quanto aos elementos visuais, devem ser especialmente examinadas as reproduções da obra de Jacques Callot, que deixou registrados momentos fundamentais da gestualidade da commedia dell'arte. O conjunto de gravuras de sua autoria, denominado Balli di Sfessania, é um dos mais valiosos documentos para o estudo dos elementos visuais da commedia dell'arte e vem, no geral reproduzido em praticamente todos os livros sobre o assunto, constituindo informação essencial tanto para o pesquisador quanto para o diretor teatral interessado em fazer reviver aquele tipo de teatro.

Constituem-se também documentos muito importantes para o estudo do assunto: estampas da época (séculos XVI e XVII); quadros de pintores italianos e franceses, retratando personagens da commedia dell'arte; gravuras sobre cenas teatrais; croquis para projetos de cenografia; fotos de máscaras originais da commedia dell'arte, atualmente depositadas em museus; fotos de tentativas de recriação de máscaras da commedia dell'arte pela família Sartori, já no século XX; a obra de Watteau, retratando o teatro da época de Marivaux; toda a vasta iconografia sobre Molière (e, em menor escala, sobre Goldoni); fotos de encenações modernas de roteiros e peças da commedia dell'arte.

Examinando tanto os registros verbais quanto os visuais da commedia dell'arte, fica sempre evidente o seu caráter extremamente popular, o que coincide diretamente com os temas eleitos pelos roteiristas, todos eles vinculados a elementos do cotidiano: o amor, a obtenção de lucro 
(ou a sua manutenção, por meio do engodo dos incautos e da avareza), a comida e a vida como imigrante numa outra região do país, com os inevitáveis preconceitos dos citadinos contra o camponês, o rústico ou caipira (fato que dá ampla margem à utilização dos mais variados dialetos, elemento fundamental da commedia dell'arte).

Assim, poder-se-ia dizer que a commedia dell'arte vive em torno de quatro eixos fundamentais, todos eles diretamente ligados ao dia-a-dia: o amor (e o sexo), o dinheiro (obtenção e manutenção da riqueza), a comida e o trabalho.

Como se pode perceber, nenhuma perfumaria, mas muita ênfase na sobrevivência dos deserdados pela sorte, em sua eterna luta para enganar os ricos e tentar tirar deles algo com que viver melhor. Esses aspectos temáticos da commedia dell' arte, somados ao elemento cômico, denominador comum de todos os roteiros (o que lhes proporciona o acesso mais fácil ao universo da sátira), garantem a característica extremamente social dos arquétipos em que os mesmos temas - pela sua reiteração acabam-se cristalizando.

Exemplo do caráter popular/social da commedia dell' arte é a permanência de uma personagem arquetipal - o avarento -, que atravessa a história do teatro desde Plauto (com o Euclião, da Aulularia), passando por Molière (com o Harpagon, de $O$ avarento) e chegando até o brasileiríssimo Ariano Suassuna (com o Euricão de $O$ santo e a porca). Ora, tal personagem tem no Pantaleão da commedia dell'arte uma de suas variantes mais nítidas, podendo ser ele considerado tanto o elemento catalisador de traços típicos de personagens semelhantes que lhe são anteriores quanto o modelo do qual partem as posteriores. Como a essa personagem sempre se opõe uma outra, no geral pobre, esfarrapada e faminta (Arlequim), ou jovem e apaixonada (o Enamorado da filha de Pantaleão), estabelece-se, com clareza e simplicidade, a oposição entre as classes sociais, tema ao qual se juntam outras ressonâncias (filosóficas, antroplógicas, sociais, sexuais), que N. Frye (1973) estuda com brilhantismo em seu Anatomia da crítica.

Se, na Itália, a commedia dell' arte tinha relação direta com os temas vinculados ao cotidiano, o que evidencia seu caráter extremamente popular, já na França diminuiu sua eficácia social, tendendo o espetáculo para os elementos de pura diversão - razão direta, entre muitas outras, da sua decadência.

Elemento notável, no entanto, é a coragem de certas manifestações de companhias de commedia dell'arte, que encenavam peças dirigindo críticas diretamente a figuras conhecidas da época, como à protegida do 
rei Luís XIV, Madame de Maintenon, satirizada em La fausse prude pelos Comédiens du Roi, o que ocasionou a expulsão da companhia da França (fato ocorrido em 1697 e retratado por Watteau num quadro do qual resta atualmente apenas uma cópia, em gravura).

Oscilando entre a contundência da sátira social (principalmente em seus primórdios, ainda no século XVI), muitas vezes resultando em virulentas e ousadas denúncias pessoais - como a que se acabou de citar -, e o outro extremo, o do cômico pelo cômico, a commedia dell'arte tanto cumpriu uma função "prática" (no geral, coibida pela censura) quanto se permitiu o luxo da diversão pura, descobrindo e fixando as leis do cômico em fórmulas dramatúrgicas que iriam ainda ser utilizadas muitos séculos depois, em obras seguramente menos ingênuas, porém estruturalmente redutíveis àqueles modelos deixados como herança pela commedia dell'arte.

Fenômeno essencialmente popular, cheio de bufonarias e valendose de intrigas amorosas no geral complicadas, porém sempre interessantes, o espetáculo da commedia dell'arte recorre a efeitos de inequívoca teatralidade, sem meios-tons, incluindo não só fatos da realidade (às vezes representada em seus aspectos fisiológicos e sexuais os mais grosseiros), como também intervenções de invejável eficácia cômica, de que as acrobacias são talvez o melhor exemplo. $\mathrm{O}$ ator de commedia dell'arte devia ser capaz de fazer contorções, piruetas, cambalhotas, saltos mortais. (Um ator incapaz dessas artes estaria praticamente impossibilitado de representar o Arlequim servidor de dois amos, de Goldoni.) Silvio D'Amico nos informa, em Storia del Teatro Drammatico, que o Scaramuccia Fiorilli, com 83 anos, ainda distribuía chutes aos interlocutores com a planta do pé. Ainda nesse aspecto - as acrobacias -, há referências que remetem imediatamente aos números circenses (o que evidencia o filão popular a que pertencem tanto a commedia dell'arte quanto a arte do circo): era comum, na commedia dell'arte, um ator dar uma cambalhota no ar com uma garrafa cheia de vinho na mão sem derramar uma só gota. Eletrizada, a platéia com certeza devia ficar profundamente gratificada por tanta diversão.

O espetáculo da commedia dell'arte era de fácil compreensão por seu perfil muito nítido das personagens, tipi fissi mascarados - com exceção dos enamorados, que não usavam máscara e falavam o italiano de Florença -, facilmente reconhecíveis pela platéia, uma vez que se repetiam de peça para peça, variando apenas o roteiro. $\mathrm{O}$ ator-mímico que as representava era perfeitamente adestrado na arte de representar, improvi- 
sar, cantar, dançar, declamar versos, fazer acrobacias; enfim, era aquilo que modernamente se convencionou chamar de "ator total", "completo".

Mas, o espetáculo da commedia dell'arte tinha muitos outros recursos para encantar a platéia. Um deles era a flexibilidade para incorporar ou corrigir reações desta pelos lazzi (truques, manobras bufonescas desvinculadas da trama, pequenas cenas de ação rápida e cômica com o objetivo de provocar gargalhadas ou dar tempo para os demais atores realizarem tarefas necessárias, como trocar de roupa). Esses momentos de pura comicidade podiam ser introduzidos livremente em qualquer enredo, desde que o ator sentisse a conveniência ou a necessidade de fazê-lo. A commedia dell' arte utilizava, no mais alto grau, todo e qualquer tipo de recurso cômico, do mais delicado ao mais grosseiro, desde que fosse obtido seu grande objetivo, o agrado do público.

A presença de danças e canções, de caráter folclórico e facilmente reconhecíveis pela platéia, colaborava para o mesmo fim, somando-se à utilização cômica da diferenciação lingüística dos vários dialetos que grassavam por toda a Itália e que serviam para identificar a origem das personagens. Motivo de interesse e oportunidade maior para o cômico verbal, a utilização dos dialetos servia para dar vazão a um problema social da época, a presença do emigrado nas grandes cidades.

Finalmente, esse tipo de espetáculo acontecia ao ar livre, com cenografia simples, no geral um telão pintado, representando uma rua, montado sobre um estrado que também servia de camarim para os atores. Adequado para o caráter ambulante das companhias, que atravessavam a Europa de feira em feira, essa solução cenográfica servia perfeitamente a um espetáculo baseado na arte do ator, na mecânica do efeito teatral e na ação propriamente dita, componentes de inegável eficácia cênica, apesar da precariedade dos meios materiais que lhes dava suporte.

Em síntese, o espetáculo da commedia dell'arte colocava em evidência o signo teatral, abandonando por princípio qualquer tentativa de ilusionismo. Em seu estado puro, já era a manifestação - ancestral, portanto - de uma das correntes do teatro moderno, que privilegia os signos cênicos em detrimento dos signos verbais, extremamente valorizados num outro tipo de teatro em que se concebe a arte da encenação como ilustração da dramaturgia. Guardadas as profundas diferenças que caracterizam cada um deles, pode-se pensar que a commedia dell'arte antecipou, na prática, o que só muito tempo depois viria a ser teorizado (e praticado, no caso do diretor russo) por Meyerhold e Artaud, que preconizavam um teatro que nascesse do próprio palco, independentemente da dramaturgia. 
Mic (1927) nos informa que o traço característico da comédia italiana são suas personagens claramente definidas, quase invariáveis, que se reduzem a alguns tipos fixos (tipi fissi), chegando a haver total simbiose entre nome do papel, pseudônimo artístico, nome próprio e nome de personagem, como é o caso da personagem Isabella, criada pela memorável Isabella Andreini, uma das mais curiosas figuras da história da commedia dell'arte.

Os atores passavam muito raramente de um gênero de papéis para outro, cada um conservando o seu até a velhice, como é o caso do ator Zanotti, que representou o enamorado Ottavio até os 70 (quando era chamado de "il vecchio Ottavio"), ou de Giovanni Pallesini, que representou o criado cômico Pedrolino até os 87 anos.

Ainda segundo Mic, uma típica companhia de commedia dell'arte teria a seguinte composição: dois velhos (Pantaleão, Doutor); primeiro zanni (Brighella); segundo zanni (Arlequim); o Capitão; Primeiro Amoroso (Innamorato); Segundo Amoroso; Primeira Dama (Donna Innamorata); Segunda Dama; Soubrette (Fantesca). De início, as companhias eram formadas por um grupo composto de dez a quinze membros. Com o passar do tempo, esse número vai aumentando.

Um dos principais recursos para a obtenção do cômico era a fala dialetal das personagens, procedimento que, já nas Atelanas, fazia rir os romanos, para quem a língua dos oscos soava rudemente.

O uso das máscaras divulgou-se rapidamente. Elas não constituíam uma novidade, pois no Carnaval e festas aparecia uma grande quantidade delas. As máscaras eram feitas de couro molhado e eram fixas num molde, que compunha os mínimos detalhes do rosto. $\mathrm{O}$ ator perdia as possibilidades de expressão facial, pois, em vez de explorar a individualidade, assumia um tipo conhecido por todos. As máscaras da commedia dell'arte não exprimiam sentimentos como as do teatro chinês ou japonês, mas tinham um caráter invariável, obedecendo a uma imagem-tipo. Em cima desse tipo, e adaptando-se às exigências do efeito cômico, o ator improvisava.

As personagens da commedia dell'arte têm perfil psicológico rudimentar. Seus traços são sínteses arquetipais das principais funções em que se dividiam as pessoas, naquela determinada sociedade. Pantaleão é o comerciante veneziano rico e egoísta, sempre à procura de jovens donzelas. Avarento, fraco, é de mentalidade estreita. O Doutor é o jurista de Bolonha, professor da universidade e erudito. Distingue-se pelo gosto da bebida e do falar, no qual mistura a estupidez com a sabedoria de aparência. É a imagem da falsa ciência. Veste-se de branco e preto: chapéu 
preto de abas largas, uma grande guarnição de renda branca no pescoço, punhos brancos, meias brancas e sapatos pretos. Brighella é a mola da ação na cena. Inteligente, astuto, malicioso, espirituoso, sabe tirar proveito de tudo e de todos. Arlequim é simples e ingênuo. Sempre alegre, não se perturba com nada nem com ninguém. Mais tarde, será retratado com uma inteligência mais aguda, em que a ingenuidade será uma arma de sua astúcia. Pulcinella é invejoso e impotente. Suas maldades são temperadas com libertinagem. Fantesca, a princípio, é a bronca e espantada camponesa descobrindo a cidade. Mais tarde, mudam seus trajes e suas maneiras: torna-se esperta e viva, numa evolução que se assemelha à de Arlequim. Colombina, a mais famosa das Fantescas, não usa máscara. Sempre havia um par de Enamorados e, nas companhias mais importantes, dois pares. São pessoas instruídas, muito lidas, sabendo de cor versos e canções e tendo o domínio de instrumentos musicais. Vestem-se com elegância e na moda. Não trazem máscaras e os atores que os representavam deviam ser bonitos. O Capitão assemelhase ao Miles Gloriosus de Plauto. Trata-se de um egoísta e presunçoso no falar. Porém, na hora da ação, mostra-se um covarde, cuja espada nunca sai da bainha, visto estar soldada nela. Era uma sátira contra a opressão e violência do exército espanhol, que ocupava a Itália, reforçada pela semelhança exterior entre a personagem e o oficial das tropas espanholas. Pedrolino, na Itália, é um zanni, um simples criado. Mais tarde, evolui para Pierrô, já segundo as condições do ambiente francês. Tartaglia foi usado como sátira a algum membro da administração civil espanhola. Aparecia como um notário, um pequeno empregado público, representante da administração aldeã.

Ao contrário da commedia sostenuta ou erudita, a commedia dell' arte tinha na improvisação a tônica de seus espetáculos. Como decorrência, da época áurea da commedia dell'arte não restaram senão roteiros, libretos em que eram demarcadas as cenas apenas quanto às entradas e saídas dos atores e suas ações principais, e não textos dramaturgicamente acabados. Com o passar do tempo, alguns momentos mais elaborados (principalmente os monólogos dos galãs, os Enamorados) começaram a ser escritos nos chamados Zibaldoni.

O caráter improvisado do espetáculo da commedia dell'arte dependia de atores profissionais, cheios de espírito, ágeis e sempre capazes de uma resposta pronta para qualquer eventualidade.

Cumpre lembrar que, mantendo seu caráter de improviso, as companhias de commedia dell'arte tanto se livravam dos cerceamentos da censura (como censurar um espetáculo, se não havia comprovante do que foi dito?) quanto mantinham preservadas as suas invenções, impedindo, 
assim, que houvesse roubo de idéias. O caráter de semelhança que, no entanto, persiste, quando se comparam as diversas companhias, deve-se ao substrato sociocultural comum a todas elas.

Num primeiro momento, tirava-se da comédia erudita (sostenuta) idéias para os argumentos, libretos ou roteiros. Já num segundo momento, desvinculada da comédia erudita, a commedia dell'arte volta às farsas antigas e aos mistérios medievais (com ênfase para as falas dos diabos), à procura de material bruto, tanto para suas improvisações quanto seus roteiros e lazzi. Os lazzi eram truques ou manobras bufonescas, desvinculados da trama, executados durante a preparação dos demais atores para o prosseguimento do espetáculo, distanciando e divertindo o público, e ocorrendo, em geral, no final do primeiro e do segundo atos.

Pequenas cenas bufas de ação rápida e cômica, com o objetivo de obter gargalhadas do público, renovando assim o interesse pelo espetáculo, ou então dando tempo para os demais atores executarem tarefas necessárias, os lazzi têm fornecido aos estudiosos motivos para longas polêmicas, sobretudo sobre a origem etimológica do termo. O consenso maior vê na palavra lazzi sempre a idéia de ação/ações (l'atto/gli atti; lazzo/lazzi), com o que concordamos.

Os lazzi são momentos de pura comicidade (os mais famosos são os da Mosca, da Pulga e do Macarrão), que continuaram existindo através dos tempos nas cenas mais cômicas de Molière (o antológico episódio da personagem dentro do saco, em As artimanhas de Escapino), nas gags visuais do cinema mudo (Charles Chaplin, Laurel \& Hardy), nas entrées de palhaços de circo, nos esquetes de cabaré (Karl Valentin) e do teatro de revista de caráter mais político-social.

O engodo e o qüiproquó são os dois recursos mais utilizados pelos roteiristas de commedia dell'arte. O tema do engodo, no geral, coincide com o da traição amorosa. Esse, por sua vez, em seus desenvolvimentos cômicos, vê-se plasmado em inúmeros qüiproquós, que não somente complicam a intriga, enriquecendo-a, como também proporcionam aos atores as mais variadas combinatórias para que se possa explorar o cômico de situação.

Como o tema da traição amorosa vê-se duplicado pela recíproca, ou seja, pelo tema inversamente proporcional do enganador enganado, deduz-se que a commedia dell'arte vale-se com mestria daquilo que Bergson (1960) posteriormente qualificou de "cômico pela repetição", que pode ser também exemplificado tanto pela repetição de uma mesma situação quanto pela inversão simétrica dos papéis: o traidor traído, o ladrão roubado, o enganador enganado, e assim por diante. 
Esse tipo de recurso cômico é enriquecido pelo uso constante do qüiproquó (confusão entre objetos ou pessoas tomados uns pelo outros, com os conseqüentes equívocos que podem nascer desse tipo de situação, sempre muito engraçados), que, na commedia dell'arte, vem no geral problematizado pelo disfarce, um dos recursos mais tradicionais da história do cômico, chegando aos nossos dias, já diluído, aos programas humorísticos e às novelas de televisão.

Ao lado dos recursos cômicos quanto a intriga, os roteiros da commedia dell'arte também registram outros elementos pertencentes ao universo do humor, com especial ênfase para a malícia e a obscenidade, características que se aproximam das narrativas curtas do Decamerão, de Boccaccio, e que favoreceriam uma sistematização maior, à semelhança daquela feita por Propp em Morfologia do conto fantástico, sistematização essa vislumbrada por Silvio D'Amico, em Storia del teatro drammatico, no que diz respeito à intriga amorosa.

Em sua ânsia de agradar, a commedia dell'arte não hesitava em fazer aparecer em cena elementos absurdos e intervenções mágicas, o que harmonizava com o clima geral de féerie. Por outro lado, a alusão ou mesmo representação de fatos fisiológicos e sexuais mostra que a commedia dell'arte também não vacilava diante de qualquer tipo de recurso mais grosseiro, desde que the garantisse o efeito desejado e, conseqüentemente, o agrado do público.

De um outro ponto de vista, deve-se lembrar que o nascimento da commedia dell'arte tem íntima relação com o Carnaval, herdando dele, portanto, o direito à total liberação, tanto sexual quanto social (as máscaras eram a síntese de tipos sociais, satirizados pelo teatro). A iconografia do Carnaval, de Brueghel às fotos do Carnaval carioca, comprova tanto a liberação sexual quanto a social, ambas inerentes a esse tipo de festa.

Todos esses elementos reunidos deram origem a um tipo de teatro extremamente popular, em que pesavam igualmente o caráter social e a mais pura diversão, muitas vezes plasmada em formas grotescas e obscenas, com os homens dessacralizados e reduzidos à igualdade mais baixa, onde não cabe nenhum tipo de heroísmo.

Analisados a partir do aparato teórico dado por N. Frye em seu Anatomia da crítica (1973), os roteiros de commedia dell 'arte são capazes de revelar que tudo aquilo que, à primeira vista, não passaria de simples recurso cômico, pode mudar de função e transformar os mesmos roteiros em documentos sobre as relações pessoais e sociais, numa determinada época, ou em registros do que as coletividades de então estariam desejo- 
sas de ver acontecer (o pobre enganando o rico, o moço vencendo o velho, o mais esperto vencendo o mais poderoso, e assim por diante).

\section{Três peças de Molière influenciadas pela commedia dell'arte}

\section{$O$ médico volante}

Escrita em 1659, O médico volante está inteiramente montada sobre o recurso cômico do disfarce: o hábil criado Sganarello faz-se passar por médico, na tentativa de ajudar seu patrão Valère, apaixonado por Lucille, filha do velho Gorgibus, que pretende casá-la com seu amigo Villebrequin. Muitos elementos comprovam a filiação dessa peça ao universo da commedia dell' arte: 1. presença de enamorados, sem função cômica; 2. presença de criados, equivalentes aos zanni; 3. presença do Advogado, correspondente ao Dottore; 4. marcas de improvisação nos “etc.", que encerram algumas falas ("Voyez-vous la conexité qu'il y a etc."); 5. presença de lazzi (o principal, da urina, na cena da consulta). Com um final brilhante, em que Sganarelle se desdobra em triplo papel - dele próprio, do falso médico e do irmão do falso médico -, essa peça permite a Molière tanto extravasar um de seus temas prediletos, o da sátira aos médicos, quanto exercitar-se na farsa de estrutura perfeita, da mais pura relojoaria.

\section{O ciúme do Barbouillé}

Ponto de confluência da farsa francesa com a commedia dell' arte italiana, Molière escreve $O$ ciúme do Barbouillé em 1660, após seu contato com Tiberio Fiorelli, da Companhia dos Comediantes Italianos, que com ele dividiam o uso da Sala do Petit Bourbon. Antes disso, Molière já tinha revelado forte influência dos italianos em L'Étourdi, baseado em Beltrame ( $L$ 'Innadvertito), grande sucesso em sua excursão pela província, antes da glorificação em Paris. Em 1659, os italianos deixam a França, mas não param de influenciá-la exatamente por meio de Molière, que, a essa altura, já tinha incorporado todas as técnicas que a arte dos comediantes ambulantes poderia lhe ensinar. Comprovam tal afirmativa os inú- 
meros traços coincidentes entre a commedia dell'arte e essa peça, e que podem ser assim arrolados: 1 . o tema da infidelidade conjugal é comum no teatro da época e aparece com muita freqüência, nos roteiros de commedia dell'arte, como uma das realizações do engodo, elemento estrutural e mola propulsora da intriga (além disso, é tema recorrente na obra de Molière e chega intacto - claro que com as devidas transformações - ao teatro dos dias de hoje); 2. o nome da personagem do Barbouillé contém, entre outros, o significado de enfarinhado, o que remete diretamente ao universo da commedia dell'arte em geral e ao das máscaras em particular (o ato de enfarinhar-se seria uma das modalidades do princípio do mascaramento); além disso, essa personagem encontra claras ressonâncias no Pantaleão da commedia dell'arte; 3. o Doutor, que aparece na farsa de Molière, é resultado da transposição direta do Dottore da commedia dell' arte; 4. igualmente, Cathau é a Fantesca, a criada do teatro popular italiano, adaptado pelo gênio francês.

\section{As artimanhas de Escapino}

Escrita apressadamente (o que não impediu que nela Molière mais uma vez alcançasse a perfeição), essa é uma peça influenciada tanto pelo teatro mais literário de Terêncio (Formião) quanto pela tradição mais popular da commedia dell'arte e das farsas tabarinescas. Uma peça de commedia dell'arte em francês e em prosa, As artimanhas de Escapino apresenta dois pares de enamorados, dois patrões e dois criados, numa estrutura muito semelhante à do melhor teatro italiano, com um Escapino equivalente, segundo Jacques Copeau, ao Brighella da commedia dell'arte. Com uma intriga complicadíssima, resolvida no final por vários reconhecimentos típicos do gênero romanesco (Frye, 1973), a ação é revitalizada e enriquecida pelos inúmeros recursos cômicos, utilizados em sua totalidade quase antológica, numa amostra da capacidade do autor para o gênero e culminando com a famosa cena em que Escapino persuade Géronte a entrar num saco (típico jogo de cena usado por Tabarin e que valeu a Molière severas repreensões de Boileau, em sua Arte poética). Talvez a peça francesa mais acabada dentro do conjunto formado pelas obras influenciadas pela commedia dell' arte, essa obra de Molière já atraiu grandes nomes, como os de Louis Jouvet (1917), Jacques Copeau (1921) e Jean-Louis Barrault (1949). 


\section{Duas peças de Marivaux}

\section{A ilha dos escravos}

Escrita em 1725, em um ato e em prosa, A ilha dos escravos pode ser considerada premonitória do declínio do absolutismo francês. Representada pelos Comediantes Italianos, faz parte de uma trilogia de caráter claramente social, escrita por Marivaux entre 1725 e 1728, na qual também figuram A ilha da razão e A nova colônia. Em A ilha dos escravos, Marivaux apresenta uma proposta social a partir do ponto de vista de um humanismo conciliador: numa ilha imaginária, dominada pelos escravos, há uma lei que determina que todos os antigos criados devem tornar-se senhores e que estes devem passar a trabalhar para os primeiros, trocando de nomes, roupas e funções. No final da peça, após os antigos patrões terem se conscientizado da vida duríssima que até então levavam seus criados, tudo volta ao normal, uma vez que a necessária lição moral e humanitária foi aprendida. Lembrando Swift e T. Morus, ao somar os temas da viagem imaginária e da utopia, duas formas da sátira tradicional, A ilha dos escravos traz para o teatro o debate de idéias, a investigação moral e filosófica das relações humanas, ampliadas para exame, especialmente no que tange aos conflitos entre as classes sociais. Como em Jogos do amor e do acaso, também em A ilha dos escravos há a troca de roupas e de identidades entre patrões e criados, porém não se trata aqui de um disfarce, de um estratagema no nível da intriga, mas de uma ação às claras, com o preciso significado de indignação contra a presunção, na cena ("metalingüística") em que os criados representam seus patrões, ridicularizando-os. No fundo (e explicavelmente, se lembrarmos a época em que a peça foi escrita), Marivaux prega a boa convivência entre as classes sociais, desde que diminuídos os excessos desumanos praticados pelos patrões contra seus criados. Essa peça - curiosíssima, se comparada com o padrão a que estamos acostumados cada vez que se pronuncia o nome de seu autor-, ao mesmo tempo que recupera traços da commedia dell'arte, recicla-os radicalmente, abrandando, por exemplo, o aspecto selvagem do Arlequim tradicional e substituindo o cômico da ação e dos gestos pelo cômico verbal. Porém, o mais fascinante é ver personagens da commedia dell'arte inseridos num outro contexto - o do debate de idéias, de conflitos sociais colocados claramente - que não o da farsa bufa, e adquirindo, por conseqüência, conotações insuspeitadas (quando soterradas pelo cômico mais tradicional) e de inegável modernidade. 


\section{Jogos do amor e do acaso}

Escrita em 1730, cinco anos após A ilha dos escravos, essa peça de Marivaux constituiu o seu maior êxito, tendo sido encenada, até 1945 e só na França, quase mil vezes. No Brasil, foi representada em 1964 pelo Teatro Popular do Sesi, sob a o título Caprichos do amor. Encenada inicialmente pelos Comediantes Italianos (com quem o autor colaborou durante trinta anos), a peça é a síntese mais harmoniosa que se poderia esperar entre o espírito francês e a gênese italiana do teatro de Marivaux. Criticada, a princípio, por falta de verossimilhança, e extremamente valorizada no final do século XIX, é a peça mais brilhante no conjunto da obra de Marivaux. Influenciou, juntamente com as demais peças do autor, Musset, Cocteau e Giraudoux e deu origem, por seus jogos de palavras e sutilezas de linguagem, ao termo marivaudage, compreendido - pejorativamente - como linguagem afetada, desprovida de naturalidade, ou então estilo afetado, cheio de conceitos. Segundo Marlise Meyer (La convention dans le théâtre d'amour de Marivaux), a peça é construída sob os padrões rigorosos das exigências clássicas. Herdeiro da commedia dell 'arte, Marivaux cria em Jogos do amor e do acaso uma obra refinada, na qual foram eliminados tanto os aspectos mais grosseiros daquele tipo de teatro quanto os elementos primitivos, em termos de construção: o improviso e as máscaras são abandonados; a intriga deixa de ter construção simples, em nível mais factual, e passa a ser resultado de movimentos psicológicos das personagens, alguns de grande sutileza. No nível das idéias, Marivaux traz ainda para o diálogo o debate sobre grandes temas morais: o amor, o casamento por interesse, as diferenças entre as classes sociais, o valor pessoal de cada indivíduo, sem conseguir evitar no todo - um indisfarçável conservadorismo. Elegendo o amor como tema principal e fazendo a vida emocional das personagens tornar-se mais importante do que a ação, ao mesmo tempo que sintetiza e refina a tradição do teatro popular italiano dos séculos XVI e XVII, Marivaux prenuncia nessa peça o teatro romântico do século XIX, ao dar, tanto para os Enamorados quanto para os zanni, a mesma ação: a aventura amorosa. Com isso, desloca o enfoque principal do conflito de classes para as peripécias afetivas, igualando a todos num só destino, o amoroso.

\section{Duas peças de Goldoni}

Carlo Goldoni surge providencialmente no panorama do teatro italiano, num momento em que a commedia dell'arte, após ter passado por seu 
período áureo e por variadas razões, começa a dar sinais de decadência. Diante desse quadro, Goldoni propõe-se a "reformar" o teatro de sua época. $\mathrm{O}$ teatro cômico mostra exatamente os percalços vividos por ele nessa tentativa.

Os pontos principais da "reforma" goldoniana podem ser assim arrolados: 1. elaboração dos argumentos das comédias a partir de situações tiradas da realidade; 2 . aprofundamento psicológico das personagens; 3. redação integral de todos os diálogos desenvolvidos entre as personagens, com a conseqüente eliminação do caráter de improvisação inerente aos antigos roteiros; 4. eliminação do caráter pornográfico que vinha marcando os espetáculos da commedia dell'arte, recuperando-se a ética e a função educadora do teatro; 5 . valorização do ator, por meio da escrita dramatúrgica que lhe é mais adequada; 6. registro artístico de uma nova classe social emergente, a burguesia; 7 . aproveitamento do significado social das máscaras, utilizadas como síntese dos eixos principais em que se subdivide a sociedade; 8. recusa da commedia dell'arte como tal e - ao mesmo tempo - fixação de suas características por meio das inúmeras peças que escreveu, utilizando-se de seus elementos mais importantes.

\section{Arlequim servidor de dois amos}

Mortes em duelos, compromissos matrimoniais assumidos entre os pais dos noivos, a contragosto dos filhos; reaparecimento de pessoas consideradas mortas; moças excêntricas disfarçadas em roupas masculinas; heranças complicadas; um assassino apaixonado pela irmã de sua vítima e, no meio de tudo isso, um criado que, para viver e comer melhor, trabalha ao mesmo tempo para dois patrões, hospedados num mesmo hotel: eis aí, grosso modo, os ingredientes cômicos de que Goldoni se valeu para construir sua obra-prima de engenhosidade teatral. Toda essa grande quantidade de recursos cômicos, no nível da intriga, no fundo encobre um tema profundamente social, ou seja, a sobrevivência dos pobres, num mundo em que só os ricos têm tempo para o amor e o lazer. É curioso notar que, da mesma maneira que Goldoni parece ter utilizado um roteiro francês como base para escrever essa peça, adaptou-a novamente para roteiro de improvisação, vencido pelas exigências do público francês, ávido de commedia dell'arte improvisada, após sua chegada a Paris, em 1762, traindo assim suas próprias convicções, nessa altura mais 
do que estabelecidas e cristalizadas. O que se pode deduzir é exatamente o caráter de intercambialidade, no nível dramatúrgico, que existe entre um roteiro de commedia dell'arte e um texto completamente escrito, caráter esse facilmente operacionalizável por um escritor de gênio, como o foi Goldoni.

\section{O teatro cômico}

Verdadeira poética goldoniana, $O$ teatro cômico é um documento indireto de toda uma fase do teatro italiano. Seu exacerbado grau de metalinguagem coloca-o numa das vertentes mais dinâmicas da arte moderna, ou seja, aquela na qual as obras refletem sobre si mesmas. No caso específico de $O$ teatro cômico, os atores de uma companhia de teatro discutem - entre tantas outras coisas - se devem abandonar a tradição da comédia improvisada (a commedia dell'arte propriamente dita) em prol da adoção de uma nova forma de se fazer teatro, com o texto totalmente escrito por um poeta (Goldoni, refletido no próprio texto). Em síntese, Goldoni não somente provocou a passagem da comédia improvisada para a comédia totalmente escrita, como elaborou um texto teatral onde registrou minuciosamente a repercussão, no comportamento dos membros de uma típica companhia de teatro (a sua?), das novidades trazidas por ele mesmo para o teatro italiano e - dada a importância e influência deste - para o teatro universal. Em suma, com a simples leitura deste texto de Goldoni, tocamos num dos momentos mais importantes de toda a história do teatro. Já é lugar-comum a possibilidade de leituras cênicas modernas de textos muito distanciados do século XX. No caso de Goldoni, tal fato se dá não só por sua técnica teatral que, apesar da passagem do tempo, permanece impecável quanto a eficácia cênica, mas também pela abordagem crítica das relações sociais, traço característico que possibilita a leitura cênica moderna, libertando sua obra das vitrines de museu.

\section{Uma fábula de Gozzi: Turandot}

Em O teatro cômico, Goldoni expõe suas idéias a respeito da "reforma" do teatro italiano em geral e da commedia dell'arte em particular, já desgastada e decadente, propondo um teatro baseado na observação 
dos costumes e escrito em prosa, numa tentativa de captar a fala comum das pessoas. Pois é exatamente contra isso que se insurge seu opositor Carlo Gozzi, um defensor do purismo da commedia dell'arte e da preservação das tradições teatrais, acrescentando-se a manutenção do verso, da rima e da temática fantástica, em contraposição direta ao realismo de Goldoni. Encenada em 1922 por Vachtangov e transformada em ópera por Puccini, Turandot foi escrita, como as demais peças de Gozzi, para a Companhia Sacchi, à qual o autor se associara. A ação de Turandot acontece na China e é inspirada na tradução de contos árabes e persas. $\mathrm{Na}$ intriga, cruzam-se dois planos distintos: o primeiro é representado pelo eixo amoroso (Turandot, Calaf e a decifração do enigma proposto pela princesa aos seus pretendentes); o segundo é representado pelo eixo cômico e inclui as personagens da commedia dell'arte propriamente dita (Pantaleão, Brighella, Tartaglia e Truffaldino). As peças de Gozzi, por ele denominadas "fábulas", desenvolvem todos aqueles elementos característicos da fase final da commedia dell'arte, com ênfase para a intriga romanesca e a interferência do sobrenatural, exacerbando-se assim o plano da fantasia. Além disso, a recorrência a temas tradicionais (a execução dos pretendentes da princesa virgem, a decifração de enigmas) coloca Gozzi numa vertente muito rica, aquela em que o inconsciente coletivo, de forte valor antropológico e psicanalítico, se faz presente com muita intensidade (como no caso da prova sacrificial, anterior à consumação do casamento). O cruzamento de eixos amoroso e cômico resulta no grotesco, que dois séculos depois daria ao diretor russo teatralista Vachtangov todas as oportunidades para as mais belas pirotecnias quanto à encenação, considerada clássica no gênero.

\section{O entremez e a commedia dell'arte}

$\mathrm{O}$ entremez (divertimento entre dois momentos de um banquete; pequena peça cômica realista, de curta duração, com personagens tiradas do povo) pode ser considerado, no século XVIII, como a forma-herdeira da commedia dell'arte que floresceu nos séculos XVI e XVII e também como a precursora do teatro de costumes, que aparecerá no século XIX.

Geralmente envolvido em confusões terminológicas (onde aparece denominado como comédia, farsa, drama gracioso, graciosa peça ou pequena peça), o entremez mantém, no entanto, sempre a mesma função: o riso. 
No século XVIII (o Século de Ouro do entremez em Portugal), houve grande influência estrangeira, com a chegada, da França e da Itália, de cantores, dançarinos, compositores, atores, cenógrafos. Molière e Goldoni são representados, adaptados e imitados, o que comprova a conexão existente entre a commedia dell'arte e o entremez.

Outros elementos em comum podem ser assim resumidos: 1 . caráter no geral anônimo; 2 . tratamento burlesco e irreverente de temas do cotidiano; 3. concentração cômica, independente de o texto ser escrito em prosa ou em verso; 4. personagens com nomes e/ou características da commedia dell'arte (Pantaleão, o criado astucioso, a criada ladina, o enganador enganado, o sovina, o criado esfomeado, o velho apaixonado pela criada astuciosa, o vaidoso, os pares cômicos etc.); 5. presença de recursos típicos do espetáculo da commedia dell'arte (danças, cantigas, pancadarias, bastonadas, disfarces); 6. ambiente de praça pública, representada no cenário, de festa popular e de feira.

Publicado precariamente, em forma de folheto de cordel, o entremez pode ser considerado o elemento intermediário entre o roteiro de commedia dell'arte e a dramaturgia mais desenvolvida do século XIX.

No geral satírico, o entremez vale-se do esquematismo das personagens (o que equivaleria às máscaras da commedia dell'arte). $\mathrm{O}$ melhor exemplo pode ser dado pelo Peralta, equivalente ibérico do Mascarille de As preciosas ridículas, de Molière: máscara social permanente, é sempre a mesma em diferentes entremezes, o que corresponde aos tipi fissi da commedia dell'arte, que permaneciam idênticos e repetitivos, apesar da extrema variedade de enredos nos quais interferiam.

Outro aspecto importante é a presença do elemento picaresco, denominador comum de variadas manifestações populares e que acaba se transformando numa espécie de fio condutor, que orienta quem pretende "ler" a continuidade dessas manifestações através dos tempos.

\section{Decorrências modernas da commedia dell'arte}

O cinema mudo (Charles Chaplin, Laurel e Hardy) aproveita, no nível do cômico e da criação de personagens, muitos elementos deixados pela commedia dell'arte. O clima geral é extremamente popular (o que não quer dizer que não haja refinamento dos recursos); o fato de não haver fala sonorizada faz que seja valorizado o cômico visual, com ênfase para a mímica do ator; a temática é sempre de fácil compreensão e gira, 
com freqüência, em torno da sobrevivência dos deserdados pela sorte, estabelecendo-se de imediato, por contraposição, a temática social ( $L u$ zes da cidade, de Chaplin, é exemplar); as personagens são tipi fissi: mudam os filmes e elas permanecem sempre as mesmas, facilmente identificáveis pela platéia, que se delicia com os bufões esfomeados, apaixonados por alguma bailarina etérea e sempre em luta com algum magnata grosseiro e poderoso; as gags (equivalentes modernas dos lazzi) sucedem-se de filme para filme e atualmente fazem parte de antologias, o que comprova seu caráter independente do enredo (Charles Chaplin, mais uma vez, não pode deixar de ser citado); o enredo é simples, porém enriquecido pela série infinita de qüiproquós armados pela personagem central que, em sua permanente ingenuidade, está sempre criando confusões. Tudo, enfim, concorre para o cômico e, em alguns filmes, ele é tão elaborado que atinge a categoria de modelo, de cômico puro.

No circo, encontramos outra vertente da arte popular e, como no cinema mudo, também ele é um lugar onde ecoam características da commedia dell'arte, principalmente nos clowns, maior ponto de contato entre as duas manifestações.

Brooks McNamara, especialista no assunto, valoriza todo e qualquer tipo de espetáculo teatral popular, ao contrário daquela linha de crítica que só reconhece o teatro feito a partir da dramaturgia erudita, considerada padrão de teatro sério. $O$ autor destaca os palhaços, melhor ponto de intersecção entre a commedia dell'arte e o circo: "Quando a representação aparece no circo - como é o caso dos palhaços - tende a centralizar-se em personagens arquetípicos e sem complexidade, em cenas simples e altamente pantomímicas. É a representação teatral em sua forma mais antiga e tradicional".

O autor relaciona também as técnicas do circo com o teatro experimental (que parte da ruptura com o teatro realista) e exemplifica com os melhores grupos desse tipo de teatro, todos eles filiados à linha do teatro teatral (teatralismo), de que Meyerhold foi o principal defensor (junto com Evreïnov, que reivindicava a criação do termo e do conceito): Living Theatre, Open Theatre, Bread and Puppet, Ridiculous Theatre, Performance Group, Théâtre du Soleil (de Arianne Mnouchkine), Le Grand Magic Circus (de Jerôme Savary), entre outros.

Em síntese, estamos num universo onde não destoam os elementos grotescos, musicais, cômicos, com grande ênfase aos valores dos saltimbancos e dos atores burlescos, universo esse que pode ser resumido na figura do clown, que reuniria elementos variados, oriundos de fontes diversas, mas unidos sob o signo da arte cênica e de caráter popular. Há 
grande semelhança não somente das entrées de palhaços com os roteiros de commedia dell'arte, como também com os esquetes de Karl Valentin, cabaretista alemão que influenciou o jovem Brecht.

No teatro de revista, podem também ser encontrados ecos da commedia dell'arte nos variados esquetes que se intercalavam entre os números musicais: os comediantes criavam, com extrema rapidez e sempre baseados em fatos da atualidade, pequenas cenas cômicas, em que satirizavam pessoas importantes, no geral políticos, desmascarados em seus comportamentos demagógicos. No Brasil, essa forma de entretenimento desapareceu e foi absorvida pelos programas humorísticos de televisão.

\section{A commedia dell'arte e a estética teatral no século XX}

O naturalismo, estética que floresceu, no teatro, no final do século XIX, almejava banir o artificial e fazer do teatro o espelho da vida. Entre seus defensores, destacam-se Zola, Henri Becque, André Antoine, Strindberg (primeira fase), Gorky e G. Hauptmann.

O teatralismo, que se opõe frontalmente à estética anterior, implantou-se a partir de 1900, propondo exatamente o contrário: mostrar que, em teatro, tudo é propositalmente artificial e que teatro não é vida, é tautologicamente - teatro. Meyerhold, Vachtangov, Taïrov e Evreïnov (criador do termo), expoentes do teatro russo de vanguarda, são os maiores defensores dessa maneira de ver e praticar a arte cênica.

Por seu exacerbado grau de teatralidade, a commedia dell'arte foi eleita como a ponta-de-lança na luta dos teatralistas contra a estética do naturalismo, defendida e praticada, na maior parte, pelo Teatro de Arte de Moscou, dirigido por Stanislavski, que, curiosamente, prestigiava e patrocinava as pesquisas dos teatralistas, o que demonstra seu alto grau de discernimento artístico.

Meyerhold, o mais importante dos teatralistas, valorizava o mímico e o comediante ambulante e, em contrapartida, desprezava os elementos retóricos do teatro, que julgava mais bem situados numa cátedra. Meyerhold propunha uma volta às origens, quando as leis fundamentais da teatralidade imperavam soberanas.

Precursor de Brecht, Meyerhold já pregava o distanciamento e defendia o grotesco como uma das técnicas para sua obtenção.

Valorizando o movimento como o elemento mais específico do teatro, Meyerhold propunha uma volta ao passado, não como uma reconsti- 
tuição de caráter museológico, mas como um estudo para coleta de material apropriado para a construção de um novo fazer teatral.

Em seus espetáculos, Meyerhold incorporava o circo, o teatro de feira, as marionetes, o grotesco, a hipérbole, a pirotecnia, sempre valorizando o estilo popular. A barraca de feira, de A. Blok, O véu de Colombina, de A. Schnitzler, Arlequim casamenteiro (roteiro), A grande lixí$v i a$, de Maiakovski, são algumas de suas direções em que o lastro popular esteve mais evidente.

Em suas encenações, Vachtangov pretendia revelar tudo aquilo que o espectador não costuma ver, principalmente no teatro naturalista: as trocas de cenário, de dispositivo cênico e de luz. Para ele, a sucessão de quadros devia ser resolvida à vista dos espectadores. Buscava viabilizar a idéia - metalingüística - do "cenário dentro do cenário", do "palco dentro do palco", para mostrar o ator vindo do camarim e esperando sua entrada em cena, o que equivaleria à idéia de incorporação da sala de ensaio à cenografia, idéia essa paralela, quanto a natureza, a duas de suas predileções: exibição das máquinas que sustentam os cenários e revelação, em cena, da técnica de metamorfose do ator em personagem, que habitualmente ocorre nos bastidores.

Admirador da commedia dell'arte, Vachtangov via na interpretação da Máscara italiana a técnica (extremamente brechtiana) de, permanecendo o ator o mesmo, encontrar e encarnar traços característicos de um papel. Sua encenação mais famosa, além de $O D y b u k$, e estudada até hoje nos principais compêndios sobre direção teatral, foi A princesa Turandot, de Carlo Gozzi, grande defensor da commedia dell'arte mais tradicional e ferrenho opositor da "reforma" goldoniana.

Menos relacionado do que os anteriores com a commedia dell'arte, mas profundamente empenhado na renovação do teatro por meio da superação do naturalismo pelo teatralismo, Taïrov destaca-se do grupo pela sua recusa do caráter social do teatro e pela valorização quase que tão-somente do seu aspecto puramente estético.

No início de sua carreira, Tä̈rov opôs-se tanto ao naturalismo do teatro de arte de Moscou, quanto ao teatro simbolista, então praticado por Meyerhold. Valorizando profundamente o ator, pregava o afastamento dos diletantes da arte. Sua grande preocupação com a plasticidade do espetáculo resultava em peças construídas sobre a relação entre os movimentos dos atores e o espaço cênico, sempre numa perspectiva o mais expressiva possível. Adepto da hiperteatralização, não hesitou em incorporar as técnicas da pantomima, do grand-guignol, da opereta e do circo. No final da vida, pressionado por seus inimigos todopoderosos, vol- 
tou-se para o naturalismo, que o realismo socialista lhe impunha, obviamente sem o brilho demonstrado em sua fase teatralista.

Na França, Jacques Copeau, considerado o renovador do teatro do seu país no período compreendido entre as duas guerras, deixou importante contribuição no que diz respeito à reabilitação da commedia dell' arte no século XX.

Contrário ao realismo, Jacques Copeau pregava o respeito religioso ao texto teatral e ao seu autor, considerando este último o diretor mais capacitado para a encenação de sua própria obra, por conhecê-la melhor do que ninguém.

Curiosamente, é esse mesmo homem que vai valorizar um tipo de teatro onde o movimento do ator sobrepuja a palavra literária, ou seja, a commedia dell'arte.

Em seu pequeno teatro, o Vieux-Colombier, a partir de 1913, num cenário reduzido aos mínimos elementos funcionais, Copeau encena Shakespeare e Molière e dá mais importância ao ator do que aos aspectos materiais do espetáculo, pregando "um palco nu para uma obra nova".

Em 1920, Copeau funda a Escola Profissional do Vieux-Colombier, onde a formação estética e técnica do ator era feita pelos ensinamentos de Stanislavski, Appia, Craig e da commedia dell'arte. Michel St. Dennis, continuador de seu trabalho, permanece propagando os métodos da commedia dell'arte na formação do ator.

Copeau encenou um grande número de obras vinculadas direta ou indiretamente à commedia dell'arte: As artimanhas de Escapino, de Molière; A estalajadeira (Mirandolina), de Goldoni; A princesa Turandot, de Carlo Gozzi.

\section{O carnaval e a commedia dell'arte}

Em suas Memórias, Goldoni conta que o Carnaval de Veneza, no ano de 1748, começou com a representação de sua peça a Viúva astucio$s a$. Nela, uma viúva mascarada consegue pôr à prova a seriedade das propostas de casamento de seus quatro pretendentes. Uma das últimas noites de Carnaval e As brincadeiras do Carnaval (em dialeto vêneto) são duas outras peças de Goldoni que também incorporam o mesmo assunto.

Shakespeare registra o tema em duas de suas peças mais famosas: Romeu e Julieta (Ato I) e Muito barulho por nada (Ato II, Cena I); Mozart aproveita o assunto em Don Giovanni (fim do I Ato); Johan Stra- 
uss Filho compôs um baile à fantasia para $O$ morcego (II Ato) e Verdi criou o mais famoso baile de máscaras para Un ballo in maschera (último ato).

No Brasil, o Carnaval já apareceu em Mimoso colibri, de Armando Gonzaga; O Carnaval de 1882, de Moreira Sampaio; Aventura carnavalesca e $O$ cordão, de Arthur Azevedo. Mais recentemente, Rei Momo, de César Vieira, também aproveitou o tema. Quanto à encenação, é antológica a cena da passagem do bloco carnavalesco em Macunaíma, adaptado de Mário de Andrade, sob a direção de Antunes Filho.

Nos anos 20 e 30, no Rio de Janeiro, as músicas carnavalescas eram lançadas publicamente pelas revistas musicais. Com sua decadência e com o sucesso do cinema, o lançamento das músicas de carnaval passou a ser feito pelos filmes, como $A$ voz do Carnaval (Cinédia, 1933), Alô, alô, Brasil e Alô, alô, Carnaval.

Arlequim, Pierrô e Colombina, o famoso triângulo herdeiro da commedia dell'arte, habitam as telas de cinema e as letras de músicas populares brasileiras desde 1916, quando foi realizado o filme carnavalesco em cinco partes Pierrô e Colombina, aproveitando o sucesso da valsa, de mesmo nome, de autoria de Oscar de Almeida e Eduardo das Neves. Dessa data, até Quando o Carnaval chegar, de Cacá Diegues, com músicas de Chico Buarque de Holanda, há toda uma trajetória, tanto da música popular quanto do cinema, girando em torno do mesmo tema, o Carnaval.

Roberto da Matta cultiva o tema em profundidade, vendo o Carnaval carioca como um rito de passagem, contrapondo-o a paradas cívicas e procissões religiosas. Um outro tema, também estudado por ele - o picaresco--, pode igualmente ser colocado no mesmo cadinho onde se juntam a commedia dell' arte, o Carnaval e a música popular brasileira. É uma aproximação lato sensu, mas não desprovida de fundamento, uma vez que podemos ver, tanto no Malasarte do folclore brasileiro quanto no Macunaíma marioandradino, as mesmas características arquetípicas do Arlequim, personagem eminentemente picaresca e que aparece, com freqüência, tanto na arte popular quanto na erudita, ainda que disfarçada sob vestes diferentes, mas sempre mantendo seus traços de irreverência e picardia.

O mesmo se dá no teatro brasileiro, onde também chegou esse espírito picaresco, que atravessa obras fundamentais da nossa literatura, resultando numa obra dramatúrgica de grande importância dentro da história do teatro brasileiro, ou seja, o Auto da compadecida, de Ariano Suassuna. Nessa peça, a figura central, João Grilo, é o próprio Arlequim 
moderno, e faz, junto com Chicó, a outra personagem com quem divide a autoria de inúmeras tramóias e qüiproquós, o mesmo par de zanni que, na commedia dell'arte, opunha-se a Pantaleão, comerciante veneziano enriquecido, aqui transformado num abastado padeiro nordestino, cuja mulher alimenta o cão de estimação com bife passado na manteiga, para desespero dos dois esfomeados bufões.

\section{Conclusões}

As formas de arte popular são perenes e, entre elas, o teatro mostra tal aspecto com muita evidência. A commedia dell'arte, considerada o momento máximo da história do teatro popular, reaparece transformada, em graus variados, no próprio teatro e em outros veículos de comunicação artística e de entretenimento (circo, cinema, cabaré, televisão), o que comprova a importância daquele tipo de manifestação, influenciando a dramaturgia e a encenação, no caso do teatro, até os nossos dias.

O estudo da commedia dell' arte leva a implicações estéticas das mais relevantes, constituindo tema que interessa sobremaneira à teoria geral do teatro. De surpreendente modernidade, a commedia dell'arte costuma, no entanto, receber apenas tratamento historicista. A abordagem diacrônica do fenômeno pode ser complementada e enriquecida pela visão sincrônica deste.

O modelo deixado pela commedia dell'arte é perfeitamente operacionalizável em nossos dias, tanto no nível da dramaturgia quanto no da encenação. Experiências realizadas comprovam a possibilidade de criações dramatúrgicas a partir de improvisações dos atores. Complementarmente, a direção de espetáculos, a partir de textos totalmente escritos, pode beneficiar-se de exercícios em que estes são tomados como roteiros para improvisações dos atores, o que comprova a intercambialidade existente entre roteiro e texto dramatúrgico definitivo.

A estreita correspondência entre a commedia dell'arte e as artes plásticas do seu tempo, que registraram, em vasta iconografia, detalhes importantíssimos para o estudo e recuperação daquele modo do fazer teatral, comprova o permanente diálogo entre as diversas artes.

A arte popular, em geral, e a commedia dell'arte, em particular, têm relação direta com temas fundamentais do cotidiano: amor, dinheiro, comida e trabalho, o que resulta diretamente na enfatização do seu aspecto social. No caso da commedia dell'arte, as personagens permanentes (tipi fissi) são o produto da redução da sociedade a poucos arquétipos 
fundamentais, reoperacionalizáveis em nossos dias, desde que sejam satisfeitas algumas exigências superficiais de adaptação, uma vez que um avaro é sempre um avaro, seja em Veneza, no século XVI, ou em São Paulo, no século XX. Além disso, os recursos constantes e repetitivos dos roteiros de companhias diferentes comprovam a existência de um mesmo lastro, do mesmo substrato sociocultural, comum a todas elas. A semelhança com os dias atuais pode ser verificada a partir do exame dos temas e estruturas em que esses elementos recorrentes se cristalizaram.

A diversão pura, o cômico pelo cômico, a comicidade aproveitada em todas as suas possibilidades, sem preocupação com escrúpulos de bom e mau gosto, são as características do teatro popular que garantem o agrado do público e a perenidade desse tipo de manifestação artística. Aparentemente apenas recurso de manutenção do interesse, o cômico e a sátira resultam em algo muito mais relevante, ou seja, a dessacralização do ser humano em sua permanente e muitas vezes ridícula e inglória tentativa de enobrecimento.

O espetáculo da commedia dell'arte pode ser considerado o melhor paradigma dos recursos do teatro popular e, mais modernamente, das artes que lhe são homólogas, como a do circo com seus clowns. A precariedade das condições materiais em que eram realizados os espetáculos levou à exacerbação do signo teatral em si, utilizado em seu mais alto grau de eficácia. Tal realidade leva atualmente a uma das mais importantes polêmicas da moderna teoria do teatro, ou seja, a da especificidade da arte teatral.

Molière, Marivaux, Goldoni e Gozzi comprovam a importância da influência deixada pela commedia dell'arte, multiplicada pelos inúmeros outros textos inspirados por eles. A análise de suas peças comprova a existência de uma ligação direta da arte ingênua do teatro popular da commedia dell'arte com a grande dramaturgia dos clássicos. A recuperação e a reciclagem dos traços fundamentais da commedia dell'arte, com o conseqüente aperfeiçoamento do cômico grosseiro, o refinamento de recursos, a ampliação do significado social das máscaras e o acréscimo de aspectos fantasiosos e poéticos, só podem comprovar a intercambialidade de processos, capaz de existir entre as artes popular e erudita.

A arte popular é um fio permanente que vai de país para país, atravessando os séculos e tomando formas aparentemente diferentes, porém todas elas atualizações de um mesmo denominador comum. O entremez, em Portugal, no século XVIII, comprova a existência dessa linha de manutenção da arte popular, constituindo-se elemento intermediário entre a commedia dell'arte dos séculos XVI e XVII e a dramaturgia do 
século XIX, da qual nosso século é herdeiro. A commedia dell'arte tem decorrências modernas também no cinema, no circo, no teatro experimental e no cabaré político-literário. A commedia dell'arte adquire, assim, importância fundamental para a estética teatral do século XX, uma vez que foi a pedra-de-toque na passagem do naturalismo para o teatralismo, tanto no teatro russo quanto no teatro francês de vanguarda, no início desse século.

No Brasil, a commedia dell' arte ressoa no nosso Carnaval, herdeiro do Carnaval veneziano, no qual apareceram as tradicionais máscaras de Arlequim, Pierrô e Colombina. Traços do teatro popular italiano podem ser ainda detectados na revista musical (incorporada mais tarde pela televisão e seus programas humorísticos), no cinema brasileiro (filmes carnavalescos da Atlântida) e na literatura de linha mais popular (que elege o pícaro como personagem central). No teatro, a commedia dell' arte ecoa indiretamente em Martins Pena (comédia de costumes do século XIX) e na dramaturgia de Ariano Suassuna, que incorpora o folclore. Quanto à atuação, Antônio Carlos Nóbrega e Dercy Gonçalves são dois artistas vivos que comprovam a perenidade de um tipo de teatro popular baseado essencialmente na arte do ator. Em síntese, como já disse Meyerhold, "o teatro de feira é eterno. Seus heróis não morrem nunca. Eles se contentam em trocar de aparência e em tomar formas novas".

VENDRAMINI, J. E. The Commedia dell'arte and his reoperation. Trans/For-

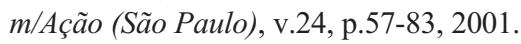

- ABSTRACT: Analysis of the commedia dell'arte from a historico-critical perspective which emphasizes the various forms of its appropriation in the $20^{\text {th }}$ Century. The themes of transformation of the open air theater into indoor theater and the extension of the model of the commedia dell'arte to other art forms of the $20^{\text {th }}$ Century, such as the silent movies, the circus and the Carnival will be brought to light from elements of the commedia dell'arte.

- KEYWORDS: Commedia dell'arte; open air theater; indoor theater. 


\section{Referências bibliográficas}

BERGSON, H. O riso. Lisboa: Guimarães Editores, 1960.

BERRETTINI, C. Duas farsas: o embrião do teatro de Molière. São Paulo: Perspectiva, 1979.

BOIADZHIEV, G. N. et al. História do teatro europeu. Lisboa: Prelo, 1960.

CHACRA, S. Natureza e sentido da improvisação teatral. São Paulo: Perspectiva, 1983.

COLE, T., CHINOY, H. K. Actors on acting. New York: Crown Publishers, 1978.

CONRADO, A. (Org.) O teatro de Meyerhold. Rio de Janeiro: Civilização Brasileira, 1969.

DUCHARTRE, P. L. La commedia dell'arte. Paris: Edition D'Art et Industrie, 1955.

FRYE, N. Anatomia da crítica. São Paulo: Cultrix, 1973.

GARFEIN, H., GORDON, M. The Adriani Lazzi of the commedia dell'arte. The Drama Review (New York), v.22, 1978.

JACOBI, R. A expressão dramática. São Paulo: MEC-INL, 1956.

LA COMMEDIA dell'Arte à travers les masques de Amleto et Donato Sartori. Bouffoneries, n.5/6. Cazilhac: Bouffons du Midi, 1982.

MASQUES du carnaval à la commedia dell'arte. Bouffoneries, n.1. Cazilhac: Bouffons du Midi, février 1980.

MAZZONE-CLEMENTI, C. Commedia and the actor. The Drama Review (New York), v.18, n.1, 1974.

MIC, C. La commedia dell'arte. Paris: Pléïade, 1927.

PAVIS, P. Dicionário de teatro. São Paulo: Perspectiva, 1999.

SILVEIRA, M. Goldoni na França. São Paulo: I. C. Ítalo-Brasileiro, 1981 